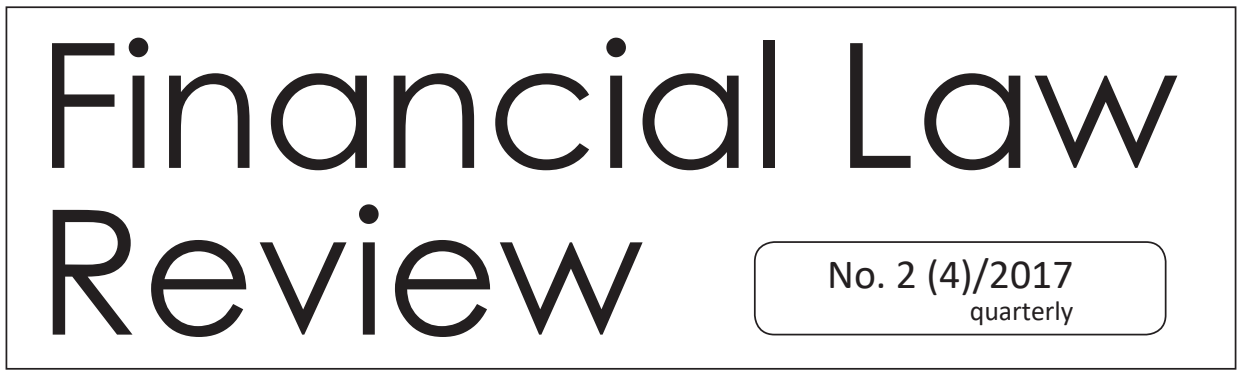

UNIVERSITY OF GDAŃSK • FACULTY OF LAW AND ADMINISTRATION

http://www.ejournals.eu • http://czasopisma.bg.ug.edu.pl

\title{
ARTICLE 9 OF THE EUROPEAN CHARTER OF LOCAL SELF-GOVERNMENT IN THE CZECH REPUBLIC ${ }^{1}$
}

Michal Radvan*

\begin{abstract}
This article deals with economic autonomy of municipalities in the Czech Republic. It analyses how the principles mentioned in the European Charter of Local Self-Government are met in the Czech legal system. The article brings the definition of local tax as an essential source of local self-government revenues and analyses possibilities of municipalities to influence local taxes. The article is relatively critical, because municipalities in the Czech Republic do not have enough revenue from local taxes. So due to their dependence on the state budget it is not possible to talk about real economic autonomy of the municipalities. The method to improve existing status is to give to the municipalities more power to decide on local taxes. The example of this solution can be found for example in Slovakia.

\footnotetext{
1 The article is a reprint of the article originally published in Finansowanie samorządu terytorialnego i jego zadań a Europejska Karta Samorządu Lokalnego. Local government financing and European Charter of Local Self-Government, J. Gliniecka, A. Drywa, E. Juchniewicz, T. Sowiński (red.), CeDeWu Warszawa 2016

* Faculty of Law, Masaryk University, Brno, Czech Republic
} 


\section{Introduction}

In 2009, I have published quite a critical text dealing with inadequate economic autonomy of local self-government units, especially municipalities, in the Czech Republic. ${ }^{2}$ I have concluded, that the economic autonomy of municipalities in the Czech Republic does not work perfectly and that there is no will to respect the basic rules set in the European Charter of Local Self-Government: municipalities do not have enough authority to decide on their own incomes and they do not have enough possibilities to get money they need from local taxes.

Nowadays, at the beginning of the year 2016, I am afraid the situation is unchanged; this is the hypothesis I will work with. The aim of this article is to summarize my existing research concerning economic autonomy of municipalities in the Czech Republic and confirm or refute the above mentioned hypothesis. I will you several scientific methods to achieve the aim: I will critically analyze the existing ways of meeting the principles of the European Charter of Local Self-Government dealing with economic autonomy (sing comparative method) and I will summarize whether this principles are met or not. If not, I will try to offer ways how to improve legal regulation in the near future.

To achieve the aim of the article, it is necessary to use existing scientific literature. But there is a lack of such a literature. I will use especially materials published by Marková, Mrkývka, Pařízková, and Netolický, and I will use as well results of my previous research cited above, of course updated.

\section{Constitutional Guarantee of Economic Autonomy of Local Self-Government Units}

Theeconomic autonomy oflocal self-government is guaranteed in the constitutional order of the Czech Republic (Constitution sensu largo created by the Constitution sensu stricto and the Charter of Fundamental Rights and Freedoms). According to Article 8 of the Constitution, the local self-government is guaranteed. The right of local communities to self-government (provided that economic independence is an essential requirement for fair local government) also includes the authorization to expect that legislators will promote economic autonomy. Economic independence is clearly reflected in the provisions of Article 101, paragraph 3

\footnotetext{
2 Radvan, M. Economic Autonomy of the Local Self-Government Units - Local Taxes in the Czech Republic. in: Zagadnienia ustroju samorządu terytorialnego w Polsce i innych państwach Unii Europejskiej. Zeszyty naukowe 2/2008. 1. ed. Szczecin : Wyższa szkoła administracji publicznej w Szczecinie, 2009. Pp. 178-193.
} 
of the Constitution, which provides that local self-government units as public corporations may have their own property and operate under their own budgets. Unfortunately, the individual legal acts do not elaborate this principle, for example there is no definition and guarantee of local taxes, as stated as well in the findings of the Constitutional Court. ${ }^{3}$

\section{Economic Autonomy of Local Self-Government Units in the European Charter of Local Self-Government}

Economicautonomyoflocalself-governmentunitsisguaranteed notonlybynational law, but by European legislation, too. The most important document in given area is the European Charter of Local Self-Government. The Charter is an international treaty adopted in the Council of Europe of 15 October 1985 in Strasbourg. Czech Republic signed the Charter on 28 May 1998 and in the Collection of Laws it was published under number 181/1999. For the Czech Republic it came into force on 1 September 1999. Unfortunately, the principles expressed by the charter are not self-executing; local self-government units cannot invoke these principles before national courts or before the European judicial authorities. ${ }^{4}$

Article 9 of the Charter, entitled "Financial Resources of Local Authorities" represents some principles of economic independence of local self-government units.

\subsection{Own Financial Resources}

"Local authorities shall be entitled, within national economic policy, to adequate financial resources of their own, of which they may dispose freely within the framework of their powers."

Czech local self-government units have right to their own financial resources, as is expressed the Constitution, ${ }^{5}$ and legal acts like small budgetary rules ${ }^{6}$ or local establishment. ${ }^{7}$

\subsection{Financial Resources Commensurate with Responsibilities}

"Local authorities' financial resources shall be commensurate with the responsibilities provided for by the constitution and the law."

\footnotetext{
3 Findings of the Constitutional Court no. Pl. ÚS 34/02, and no. Pl. ÚS 5/03.

${ }^{4}$ See Finding of the Constitutional Court no. Pl. ÚS 34/02.

5 Art. 101, paragraph 3 of the Constitution.

6 Section 7 of the Act No. 250/2000 Sb., Budgetary rules on local budgets, as amended.

7 Section 2 of the Act No. 128/2000 Sb., on Municipalities, as amended.
} 
The Czech Republic respects the rule. It should be noted that this rule should be observed constantly, regardless of changes in legislation. Perhaps that is why there are frequent views tension between the state and local authorities when the other side points to the increase in power without adequate financial compensation. But this principle must be respected: If there is the growing number of tasks and thus the responsibility of municipalities and regions to accomplish these tasks, there must be an increase of the financial resources. The thing is who and when decides these issues: they are politicians who usually change these tasks and resources at the time of budget approval by amending individual legal acts. And then there is another question: who and how is liable for misuse of these resources?

\subsection{Local Taxes}

"Part at least of the financial resources of local authorities shall derive from local taxes and charges of which, within the limits of statute, they have the power to determine the rate."

There are many books and articles about local taxes, but what is local tax? It is necessary to find the definition. Marková ${ }^{9}$ recognizes local tax, if it is considered as the instrument of the adaptation of the revenue base of local self-government, the objectives and priorities of local people. She defines the criteria which should local taxes have and as an essential criterion she indicates possessive criterion ( $\operatorname{tax}$ revenue is the income of the municipality) and the criterion of rate (the amount of tax rates is set by the municipality). The additional criteria are criterion of revenue (tax is administered by the municipality; that is why we should better talk about the administration criterion) and the criterion of decision-making (the municipality defines the tax base). No local taxes levied in the European Union, however, do meet all the criteria, and therefore the question is how many criteria must be met in order to consider a levy as a local tax. If we opted only to the first criterion, all shared taxes would be local taxes. While the second criterion would

\footnotetext{
${ }^{8}$ Marková, H. Finanční zdroje místních společenství a Evropská charta místní samosprávy v podmínkách ČR (Financial resources of local communities and the European Charter of Local Self-Government in terms of the Czech Republic). in: Radvan, M., Mrkývka, P. (ed.). Financování územní samosprávy ve sjednocující se Evropě - Sborník 1. Mezinárodního právnického symposia (CD-ROM) (Financing of local self-government in unifying Europe - Proceedings from 1st International legal symposium (CD-ROM)). Brno: Masarykova univerzita, 2005. P. 3.

${ }^{9}$ Marková, H. Vlastní nebo sdílené daně obcím? (Owned or shared taxes for municipalities?) in: Kandalec, P., Kyncl. L., Radvan, M., Sehnálek, D., Svobodová, K., Šramková, D., Valdhans, J., Žatecká, E. (ed.). Days of public law: sborník příspěvků z mezinárodní konference (CD-ROM) (Days of public law: Proceedings from international symposium (CD-ROM)). Brno: Masarykova univerzita, 2007. P. 2.
} 
be consulted, local taxes are for example all vested taxes, with some, though limited fiscal powers (for example, local taxes, and partly property tax). Using of the third criterion local taxes are all local taxes, but not the property tax. This also applies to the fourth criterion.

Babčák ${ }^{10}$ uses even five aspects crucial for the designation of local taxes:

- the municipality must be authorized to decide on the establishment or cancellation of local taxes,

- the municipality must be authorized to decide on certain structural elements of the tax (the taxpayer, subject, tax base, tax rate, the date of the tax return, payment conditions),

- the municipality must be able to significantly influence the revenue of local taxes (the power to increase or decrease basic rates, exemptions, relieves),

- the revenue must be the original income of the budget of the municipality, without any possibility to use the revenue for the needs of another budgets,

- local tax must come from local sources.

However, local taxes, as defined by Babčák seem not to exist. For example Slovak local fee on municipal waste known as the local tax is obligatory by law.

Králik and Jakubovič ${ }^{11}$ define local taxes as a kind of mandatory fiscal payments of individuals and legal entities. They are one of the sources of the local budget. They are collected from the local population or legal entities with the point of the seat, place, etc. in given municipality. In addition to the functions of supplementary sources of the local budget they may be the main source of the revenue.

Peková ${ }^{12}$ defines some of the characteristics of taxes for local budgets, for example, a stable tax base and the resulting long-term stable revenue, low risk of tax evasion and easily detectable tax liability, the inability to convert the revenue into another municipality or region, to ensure certain tax revenue and administrative modesty.

\footnotetext{
10 Babčák, V. Miestne dane a miestne poplatky - stav a perspektiva (Local taxes and local taxes - the status and outlook). in: Radvan, M., Mrkývka, P. (ed.). Financování územní samosprávy ve sjednocující se Evropě - Sborník 1. Mezinárodního právnického symposia (CD-ROM) (Financing of local self-government in unifying Europe - Proceedings from 1st International legal symposium (CD-ROM)). Brno: Masarykova univerzita, 2005. P. 1-6.

11 Králik, J., Jakubovič, D. Finančné právo (Financial law). Bratislava: Veda, 2004. P. 50.

12 Peková, J. Hospodaření a finance územní samosprávy (Management and finance of local self-government). Praha: Management Press, 2004. P. 264.
} 
Mrkývka ${ }^{13}$ gives three possible models in the construction of local taxes:

- local taxes are all the taxes with the revenue to the local budgets,

- local taxes are introduced and administered by local self-government units,

- local self-government unit is required to collect all local taxes, municipalities have the option in accordance with local conditions to adjust the taxation of corrective elements (exemptions, reductions, increasing taxes).

The first model is referred to at least rigid, respectively freest. According to that, as the local tax we could consider the Czech property tax. The second model of local taxes defines the Czech local charges and a third characteristic describes municipal taxes proposed in the Czech Republic in 2000.

In my personal view is the question of defining local taxes issue purely theoretical and not much practical. There is no doubt that the municipality must be able to assess some local taxes, however, that their right will be limited by law with regard to Article 11, paragraph 5 of The Charter of Fundamental Rights and Freedoms. And in this case it is more a political question as to whether and in what form and to what extent the municipalities will receive options to assess and / or collect local taxes. From the above mentioned definitions and on this basis I created and previously published my own definition, that the local tax would be a financial levy, determined to municipal budget that can be influenced (talking about tax base, tax rates or one of the correction elements) by the municipality. It is not crucial whether the taxpayer obtains from the municipality any consideration or if it is a regular or a single levy - local taxes include the tax in the strict sense, so the fees (charges).

Local taxes are condition sine qua non for the economic autonomy of local self-government. But when ratifying the Charter the Czech Republic made the notification that it does not consider itself bound by this provision. On the other hand, there are several local taxes in the Czech Republic. The most important one is immovable property tax. Even this tax is not administered by the municipality itself, it has several possibilities to influence the revenue: there are three possibilities of exemptions (exemption of property attached by natural disaster, exemption of agricultural lands, and exemption of property as an investment incentive), and three possibilities to apply or change coefficients that can influence the tax rate (location rent, municipal coefficient and local coefficient).

${ }^{13}$ Mrkývka, P. Některé úvahy o materiálním základu veřejné správy (Some reflections on the material base of public administration). Časopis pro právní vědu a praxi 2/2003. P. 156. 
When eliminating consequences of natural disaster, a municipality may, by its generally binding ordinance, fully or partly (as a percentage) exempt the property, which is located within its area and which was affected by a natural disaster, from the property tax for a period of up to five years. The exemption can be effective not only for the year when there is a natural disaster and for the following years, but even for the one previous taxable period. This kind of exemption is not very popular and often. If there is a natural disaster, the municipality needs more money than usual and it does not offer this exemption. Moreover, it is difficult to say what property was affected by a natural disaster (for example flats in the first floor were damaged, but flats in the fourth floor are all right).

The arable lands, hop-gardens, vineyards, orchards and permanent grass growths (agricultural lands) can be exempt by municipality's generally binding ordinance. This exemption cannot be applied on lands in developed area and build-up area of the municipality if the ordinance sets so and if these lands are determined in the ordinance by the parcel number and the cadaster area. This exemption is not used used a lot: small villages with many lands that can be exempt would lose a lot of money and in cities there are not many lands like that.

The exemption of immovable property taxation as an investment incentive is very new and it can be used for the first time in the taxable year of 2016.

Concerning coefficients, coefficient called location rent - a coefficient according to the number of inhabitants - is used only for several kinds of property: development lands, residential buildings, other structures that provide facilities for residential buildings, flats and non-residential premise not used for running business and as garages. The location rent multiplies the standard tax rate. The basic value of the coefficient is set in the act and the value is between 1,0 and 4,5 . The municipalities have right to increase (up to one level) or reduce (down to three levels) a basic coefficient by a generally binding ordinance. This coefficient is used by many czech municipalities and it has quite a long tradition especially because of its fiscal function.

Municipal coefficient can be used for the some buildings if the location rent cannot be used, it means for houses and family houses used for individual recreation, other structures that provide facilities for houses and family houses used for individual recreation, garages, structures for business activities, non-residential premises used for business activities and as garages. The municipalities have right to set this coefficient by their generally binding ordinance for particular types of structures. The value of the coefficient is at 1,5 and it multiplies the standard tax 
rate. This coefficient is quite often in the Czech municipalities especially because of its fiscal function.

The municipalities have new rights to increase the property tax from the beginning of 2009. They can set by a generally binding ordinance for all property on their area a local coefficient at 2, 3, 4 or 5. This coefficient multiplies the tax duty of the taxpayer for particular kinds of lands, buildings, non-residential premises and flats. As the mayors say (they want to be elected again), taxes are political questions. That is why they do not want to use this coefficient and increase the taxes twice, three times, four times or even five times.

There are very strict rules on the generally binding ordinances regulating property tax. They shall be send to a competent tax administrator within five calendar days of the day of validity, and they must become valid no later than 1 August of the preceding taxable period and take effect no later than 1 January of the following taxable period. Of course, if they are retroactive, they are not valid, with the exemption of the ordinances with exemptions of agricultural lands.

The Local Charges Act provides for the power of municipalities to assess local charges by means of issuing their ordinances (bylaws). Such ordinances must specify the conditions for levying, the charge rate, the charge maturity and possible exemptions, if any. The ordinances may not exceed the limits defined by the Local Charges Act (such as, for example, the absolute charge rate and the types of charges permitted). Presently, the municipalities in the Czech Republic have the opportunity to levy only the following local charges (the list is complete, i.e. municipalities are not allowed to levy any other charges):

1. Dog charge;

2. Charge for spa and recreation stay;

3. Charge for using public places;

4. Charge on entrance;

5. Charge for housing capacity;

6. Charge on communal waste;

7. Charge for permission to enter selected places by motor vehicle;

8. Charge on appreciation of building land.

\subsection{Diversified Financial Systems}

"The financial systems on which resources available to local authorities are based shall be of a sufficiently diversified and buoyant nature to enable them to keep pace 
as far as practically possible with the real evolution of the cost of carrying out their tasks."

The principle of diversified financial systems and very close to the principle mentioned in chapter 2.2 and Netolický points out there is a growing number of tasks and thus the responsibility of municipalities and regions to accomplish these tasks, but the financial resources remain the same. ${ }^{14}$ It should be noted that the diversity of potential incomes of the municipalities is maintained and this principle is respected by the Czech Republic. List of income opportunities can be found in small budgetary rules, other sources of funding may be provided through the National Fund, or various forms of irrecoverable incomes (grants, loans, and the issue of municipal bonds). However, we can hardly speak about flexibility in the Czech Republic.

With regard to the principle of diversified financial systems, it is possible to talk about fiscal federalism within the budgetary system, where there are at least two levels of decision-making. Fiscal federalism reflects organization of the state, while creating the appropriate level of public budgets - the state budget, regional budgets and municipal budgets. Process, where the powers are transferred from the center (from the state) to lower territorial units, incl. appropriate resources and decision-making on their using, is known as fiscal decentralization. Central level ensures adequate resources to ensure a certain standard of public services (for example, through vested taxes, shares of taxes, subsidies, etc.), while a lower level, which has a better knowledge of the local situation, decides on the specific conditions of the services. In this context, in some cases, there is also the transfer of the taxation powers, i. e. a lower administrative level can levy their own taxes or impose a premium surcharge on central taxes and provide a large number of public goods and services. ${ }^{15}$

Key legal act determining the tax revenue is the Act on Budget Destination of Taxes. This act tries to spread the tax revenue so that the state budget and the budgets of local self-government units would be balanced and that their fiscal capacity would relatively go in conformity. This requirement is achieved by widespread

\footnotetext{
${ }_{14}$ Netolický, M. Evropská charta místní samosprávy a financování obcí (European Charter of Local Self-Government and Financing of Municipalities). in: PFAMEI 2007. Brno: Masarykova univerzita, 2007. P. 2.

15 Široký, J. Daňová teorie s praktickou aplikací (Tax theory with practical application). Praha: C.H.Beck, 2008. Pp. 205-206.
} 
portfolio of shared taxes, which means that the share of municipalities and regions to progressive taxes as well as digressive taxes is guaranteed. ${ }^{16}$

Act on Budget Destination of Taxes, by its nature, regulates a system of vested taxes and shared taxes:

- vested taxes - the whole revenue is the income of municipal and regional budget:

- property tax is the income of municipal budget,

- corporate income tax paid by municipality is the income of municipal budget,

- corporate income tax paid by region is the income of regional budget,

- shared taxes - the revenue from these taxes is distributed among the different public budgets in the legal circumstances:

- value added tax,

- personal income tax,

- corporate income tax (except taxes paid by municipality or region).

Act on Budget Destination of Taxes regulates the determination only of a certain taxes (VAT, excise taxes, income taxes, immovable property tax and road tax); in other cases (tax on acquisition of immovable property) the revenue is the income of the state budget or municipal budgets (local charges, etc.) according to the individual act.

Tax revenues of the region budgets according to the Act on Budget Destination of Taxes are:

- share of value added tax,

- share of personal income tax,

- share of corporate income tax.

Tax revenues of the municipal budgets according to the Act on Budget Destination of Taxes are:

- property tax revenue; the beneficiary is the municipality, where the property is situated,

- share of value added tax,

- share of personal income tax,

- share of corporate income tax.

16 See Pařízková, I. Finanční právo: finance územní samosprávy (Financial law: Local self-government finance). Brno: Masarykova univerzita, 2005. P. 109. 
Other tax incomes of the municipalities according to Budget Mix Ordinance ${ }^{17}$ are local charges, resources gained by administrative activities, etc. Municipalities obtain, too:

- incomes from property and property rights of the municipality,

- incomes from economic activities of the municipality,

- subsidies from the state budget and state funds,

- subsidies from the regional budget,

- financial resources from the administrative activities of other bodies of the public administration, for example fines or other monetary charges and penalties if they are incomes of the municipalities under special laws,

- financial gifts and allowances. ${ }^{18}$

For better understanding it is possible to illustrate the budget destination of taxes in the system of public budgets:

Table 1. Budget destination of taxes in the system of public budgets

\begin{tabular}{|l|l|l|}
\hline \multicolumn{1}{|c|}{ Tax } & \multicolumn{1}{|c|}{ Specification } & \multicolumn{1}{c|}{ Budget } \\
\hline Personal income tax & & State, regional and municipal \\
\hline Corporate income tax & & State, regional and municipal \\
\hline Immovable property tax & & Municipal \\
\hline Road tax & & $\begin{array}{l}\text { State Fund of transport infrastruc- } \\
\text { ture (SFTI) }\end{array}$ \\
\hline $\begin{array}{l}\text { Tax on acquisition } \\
\text { of immovable property }\end{array}$ & & State \\
\hline Value added tax & On mineral oils & State, (SFTI) \\
\cline { 2 - 3 } Excises & Other excise taxes & State \\
\hline Customs & & State, EU \\
\hline Vignette & & SFTI \\
\hline Road toll & & SFTI \\
\hline Social insurance & & State \\
\hline Local charges & & Municipal \\
\hline Administrative charges & & State, regional and Municipal \\
\hline Environmental charges & & $\begin{array}{l}\text { State, municipal, State Fund } \\
\text { of Environment }\end{array}$ \\
\hline
\end{tabular}

17 Ordinance of the Ministry of Finance no. 323/2002 Coll., Budget Mix Ordinance, as amended.

18 See Section 7 paragraph 1 of the Act no. 250/2000 Coll., Budgetary rules on local budgets, as amended. 


\subsection{Protection of Financially Weaker Local Authorities}

"The protection of financially weaker local authorities calls for the institution of financial equalisation procedures or equivalent measures which are designed to correct the effects of the unequal distribution of potential sources of finance and of the financial burden they must support. Such procedures or measures shall not diminish the discretion local authorities may exercise within their own sphere of responsibility."

The problem is the differentiation of territorial units of the richer and poorer, which is the case of the many causes of whether affected (support for the construction leading to higher property tax revenue, their own economic activity), or not affected (setting the allocation of proceeds of centrally collected taxes) by the municipalities. Marková ${ }^{19}$ refers to the balancing of conflicting principles of deserving and of solidarity when the latter is aimed at balancing the gap between poor and rich regions.

Personally, I have to agree that the Czech Republic made the notification that it does not consider itself bound by this provision. The reason is the total number of municipalities in the Czech Republic; this number is almost 6,300 and it is the second highest number in the European Union (the first is France). There are too many small municipalities with the number of inhabitants not exceeding 1,000 people, there is even one village with only two inhabitants. Well, the economic pressure to force municipalities to merge could be the solution to decrease the number of municipalities in the Czech Republic. And of course large municipalities are offering more service to (not only their) inhabitants. On the other hand, the political solutions during the last ten years are very often opposite and small municipalities are receiving more from shared taxes at the expense of the largest four cities.

\subsection{Consultations with Local Authorities}

"Local authorities shall be consulted, in an appropriate manner, on the way in which redistributed resources are to be allocated to them."

\footnotetext{
19 Marková, H. Finanční zdroje místních společenství a Evropská charta místní samosprávy v podmínkách ČR (Financial resources of local communities and the European Charter of Local Self-Government in terms of the Czech Republic). in: Radvan, M., Mrkývka, P. (ed.). Financování územní samosprávy ve sjednocující se Evropě - Sborník 1. Mezinárodního právnického symposia (CD-ROM) (Financing of local self-government in unifying Europe - Proceedings from 1st International legal symposium (CD-ROM)). Brno: Masarykova univerzita, 2005. P. 5.
} 
The debate is undoubtedly kept, and recently more and more views and needs of municipalities are taken into account, as mentioned above. There is the same reason (too many municipalities in the Czech Republic) the Czech Republic made the notification that it does not consider itself bound by this provision.

\subsection{Grants Not Earmarked for Specific Projects}

"As far as possible, grants to local authorities shall not be earmarked for the financing of specific projects. The provision of grants shall not remove the basic freedom of local authorities to exercise policy discretion within their own jurisdiction."

This rule, of course, does not forbid subsidies in individual cases, but tries to minimize them in proportion to non-specific ones. The Czech Republic respects this principle.

\subsection{Access to Capital Market}

"For the purpose of borrowing for capital investment, local authorities shall have access to the national capital market within the limits of the law."

Grants, loans and bond issue are one of the possible sources of local self-government incomes. To all these possibilities, however, municipalities have approached with caution, because in all property relations the municipality acts in its own name, on its account, and above with its responsibility. The Czech Republic respects this principle.

\section{Conclusion}

About how seriously the issue of economic autonomy of local self-government units in the Czech Republic is taken, you can make the view in the context of the fact that the Czech Republic in ratifying the European Charter of Local Self-Government made the notification, that the Czech Republic does not consider itself bound by provisions of Article 9, paragraphs 3, 5 and 6. As mentioned above, it is quite reasonable that principles of protection of financially weaker local authorities and consultations with local authorities are not respected. On the other hand, the principle of local taxes is one of the most important principle and local taxes are condition sine qua non for right functioning of local self-government. 
For example Peková ${ }^{20}$ draws attention to the fact that for certain quality of the territorial self-government, it is necessary not only to manage its finances in certain basic principles (such as the management of the annual budget, a sufficient degree of local or regional autonomy, the principle of solidarity between richer and poorer communities, the transparency of the financial system and the associated possibility of public control, stability of the system and its rules, administrative efficiency and modesty). In this context, it should be also noted that both the current government proposals for the "Law on Local Taxes" on the basis that the role of local taxes should not be negligible, local taxes should create sufficient potential of local taxes for public services and extend the possibilities of municipalities to effectively regulate local development, were returned, respectively rejected by the Chamber of Deputies.

As it appears, municipalities and mainly regions are in drawing up their budgets dependent on the allocation of revenue (income tax, VAT), and their own options are very limited. Finally, even property tax by one hundred percent goes to municipal budgets, it is not administered by municipalities. The disposition of municipalities with taxes and the amount is modest, too. How Parízková ${ }^{21}$ notes, until the municipalities will not be able to at least partially influence the amount of tax revenue, there will still be a threat for their autonomous actions.

Example of further development in this area could be Slovakia. Local charges were simply renamed on local taxes and property tax was added to the group of local taxes. The fact that property tax is in group of local taxes means primarily the fulfilment of the principles of economic autonomy: municipalities are entitled not only to decide on the amount of the tax itself but also on the introduction of the tax. A similar change, connected with other amendments of the property tax (especially tax rates, may be tax base), if it was made in the Czech Republic, would mean a fulfilment of one of the four basic characteristics of real local self-government - economic independence (economic autonomy) of the municipalities. ${ }^{22}$ It must

\footnotetext{
20 See Peková, J. Hospodaření a finance územní samosprávy (Management and finance of local self-government). Praha: Management Press, 2004. Pp. 197-200.

${ }^{21}$ See Pař́zková, I. Finance územních samosprávných celků (Finance of local self-government units). Brno: Masarykovu univerzita, 1998. P. 116. See Pauličková, A. Zákonná úprava daňových príjmov rozpočtu obce $v$ Slovenskej republike (Legal regulation of tax incomes of municipal budgets in Slovakia). Právník 8/2003 Pp. 801-802.

${ }^{22}$ Each municipality is equipped with a certain degree of economic autonomy, it self-manages, has its own property and financial resources. See Mrkývka, P. Některé úvahy o materiálním základu veřejné správy (Some reflections on the material base of public administration). Časopis pro právní vědu a praxi 2/2003. P. 153-157.
} 
show not only in deciding on the expenditures of local self-government, but also in deciding on its incomes. Unfortunately, there were no essential legislative changes in this area between the years 2009 and 2016 and the hypothesis set in the introduction was confirmed. 